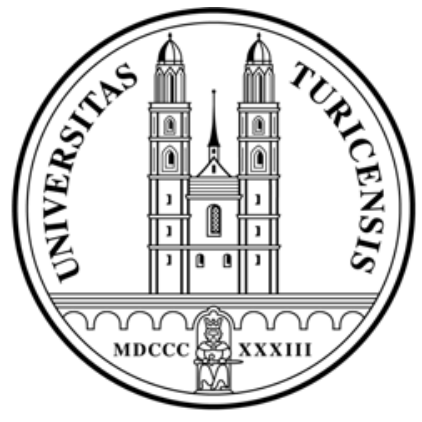

Institute for Empirical Research in Economics

University of Zurich

Working Paper Series

ISSN 1424-0459

forthcoming in: Management Inquiry 2005

Working Paper No. 187

Yes, Managers Should be Paid Like Bureaucrats

Bruno S. Frey and Margit Osterloh

July 2004 


\title{
YES, MANAGERS SHOULD BE PAID LIKE BUREAUCRATS
}

\author{
BRUNO S. FREY \\ and \\ MARGIT OSTERLOH* \\ University of Zurich \\ (this version July 24, 2004, \\ forthcoming in Journal of Management Inquiry)
}

\begin{abstract}
Corporate scandals, reflected in excessive management compensation and fraudulent accounts, cause considerable damage. Agency theory's insistence on linking the compensation of managers and directors as closely as possible to firm performance is a major reason for these scandals. They cannot be overcome by improving variable pay for performance, as selfish extrinsic motivation is reinforced. Based on the common pool approach to the firm, institutions are proposed which serve to raise intrinsically motivated corporate virtue. More importance is to be attributed to fixed pay and strengthening the legitimacy of authorities by procedural fairness, relational contracts and organizational citizenship behavior. (97 words)
\end{abstract}

Keywords: Agency theory, intrinsic motivation, crowding theory, management compensation pay for performance, organizational citizenship.

JEL Classification: D21, D23, J33, L20

\footnotetext{
* Bruno S. Frey is Professor of Economics, and Margit Osterloh is Professor of Management at the University of Zurich. E-mails: bsfrey@,iew.unizh.ch; osterloh@,iou.unizh.ch Both authors are also associated with CREMACenter for Research in Economics, Management and the Arts.
} 


\section{INTRODUCTION}

A little more than a dozen years ago, Jensen and Murphy (1990) published a paper essentially establishing the principal agent approach currently prevailing in the theory and practice of executive compensation. They argued that:

"In most publicly held companies, the compensation of top executives is virtually independent of performance. On average, corporate America pays its most important leaders like bureaucrats. Is it any wonder then that so many CEOs act like bureaucrats rather than the value-maximizing entrepreneurs companies need ...?” (p. 138).

Jensen and Murphy take it as a matter of course that bureaucratic behavior is far inferior to what a value-maximizing manager would do. They therefore conclude that:

"Cash compensation should be structured to provide big rewards for outstanding performance and meaningful penalties for poor performance" (p. 141).

Hall and Liebman (1998) integrate the comparison to bureaucrats in the title of their paper "Are CEOs Really Paid Like Bureaucrats?". However, they document that today there is a "strong relationship between firm performance and CEO compensation" (p. 654). The difference to Jensen and Meckling's views is mainly attributed to the fact that, since 1980, the largest part of pay increase is due to stock options. This dramatically increased the responsiveness of top managers' compensation to stock prices. However, this responsiveness sparked of undesired results: recently, the media have been full of accounts of managerial misbehavior (e.g. Cassidy, 2002; Useem, 2003). The exorbitant salaries of some CEOs and other top managers have made the headlines. As a consequence, the imbalances in income distribution have increased significantly. In 1970, an American CEO earned, on average, 25 times as much as an industrial worker. Twenty-six years later, in 1996, the average CEO earned about 75 times as much, taking 
only base salaries and bonuses into account. If we look at income, including exercised stock options, the income differential reaches an almost incredible level. The ratio rises from a factor of 25 in 1970 to 210 in 1996 (Murphy, 1999, p. 2553) and has risen even further to more than 500 in 2000 (Klinger et al., 2002). Has performance of firms been raised to the same extent? In his authoritative survey on "Executive Compensation" in the Handbook of Labour Economics, Kevin Murphy (1999, p. 2555) has this to say:

"Although there is ample evidence that CEOs (and other employees) respond predictably to dysfunctional compensation arrangements, it is more difficult to document that the increase in stock-based incentives has led CEOs to work harder, smarter, and more in the interest of shareholders."

In the meantime, the adverse effects of these exorbitant stock option programs became obvious. The prospect of such huge salaries has led some top managers to act in ways which are detrimental to their firms, as well as to the market system as a whole. Managers have turned from "legends" (Hegele \& Kieser, 2001) into “crooks" (Osterloh \& Frey 2004). In particular, managers have jacked up short-term profits instead of focusing on long-term opportunities, and they have neglected paying out dividends to their shareholders (Lambert, Lanen \& Larcker, 1989). Many corporate scandals are also reflected in fraudulent accounts. Well-known examples are WorldCom, Xerox and Enron. Circumstantial evidence suggests that some CEOs who fiddle the accounts are the same persons who receive exorbitant compensations, e.g. Enron's Kenneth Lay and WorldCom's Scott Sullivan (Cassidy, 2002; Salter, 2003). This relationship has also been empirically established. Over the period 1992 to 2001, it has been demonstrated that a higher amount of variable pay for performance in total CEO compensation is linked to fraud. The Securities and Exchange Commission (SEC) has officially identified 43 "fraud firms" in that period. These "fraud firms" have been compared to 2500 S\&P "innocent firms". The median change in an executive's stock and option portfolio for a 1000 dollar change in firm value (dollars-on-dollars incentive) in "fraud firms" is more than twice as high as in "innocent firms" (Johnson, Ryan \& Tian, 2003). Formal accounting restatements of publicly held companies 
between 1997 and 2002, reported in a report of the General Accounting Office (GAO, 2002), were found to be most likely in firms with a high proportion of stock options in terms of CEO pay (Harris \& Bromiley, 2004).

However, significant contributors to agency theory tend to defend the existing system of CEO compensation. But most of them admit major weaknesses in the approach. Today, Jensen (The Economist, November 16, 2002: 66; Fuller \& Jensen, 2002) accepts that the existing system of managing compensation, especially using stock options, is seriously deficient; he argues that it has proven to be "managerial heroin", encouraging a focus on short-term highs, with destructive long-term consequences. But he believes that the system can be salvaged by better-designed share options. Also Bebchuk and Fried (2003), though arguing that executive compensation is part of the agency problem itself, still believe in the basic message of agency theory: "We should like to emphasize our strong support for the general idea of equity-based compensation which, if well designed, can provide managers with very desirable incentives" (Bebchuk \& Fried, 2003, p.13, see also Hall, 2003). In their opinion, to overcome the failings identified, pay for performance must be improved.

This paper draws a different conclusion. It is argued that high-powered incentive compensation, even if it could be optimally designed, does not solve the problems identified in the corporate sector identified, but aggravates them. We suggest a model based on a new concept. The firm is analyzed as a bundle of common pool resources. These are collective goods in the form of firm specific investments, generating a joint surplus which cannot be attributed to single actors. The production of such collective goods is based on both extrinsic and intrinsic incentives. In contrast, agency theory assumes that managers' additional or marginal effort is solely motivated by one factor, extrinsic incentives. But social psychology, as well as psychological economics, indicates that individuals' motivations are more broadly based. Individuals derive utility from the activity itself or because they wish to comply with given normative standards for their own sake. The extent of intrinsically motivated behavior systematically depends on conditions which can be shaped by appropriate institutions. They approximate the conditions identified by Max Weber (1978) in his model of bureaucracy, which he takes to be the most efficient mode of governance. 
In particular, we argue that considerably more emphasis should be put on fixed salaries not dependent on variable performance criteria.

The second section discusses the deficiencies of existing approaches of corporate governance which are relevant to executive compensation. In addition to agency theory, we deal with recently developed team production models. The latter address some of the shortcomings of agency theory, but are unable to adequately take into account the problem of asymmetric information and appropriate incentives for overcoming it. In the third section, we outline our common pool approach. It is still in its infancy, though it used to be common practice before the agency approach became dominant. Prosocial intrinsic incentives play a major role in the common pool approach. Therefore, in the third section, the empirical evidence of intrinsically motivated prosocial behavior is discussed. Such behavior is not only more prevalent than economic theory assumes, but is based on preferences which can be shaped by institutional arrangements. Until recently, the majority of economists (most prominently Stigler \& Becker, 1977) assumed unchanging preferences to avoid the immunization of theoretical propositions (see Lindenberg 1984). The fifth section shows how institutions can support, or destroy, intrinsic preferences. The last section concludes.

\section{TWO APPROACHES TO EXECUTIVE COMPENSATION}

\section{Principal Agency Approach}

The corporate governance discussion is presently dominated by agency theory, both in theory and in corporate practice (e.g. Daily, Dalton \& Cannella, 2003). Firms are seen as a nexus of contracts between shareholders and CEOs pursuing their own interests. Due to "rational apathy" on the part of minority shareholders in public corporations, the control of management is transferred to the board of directors as a second level of agency (e.g. Black, 1992). In order to curb opportunistic behavior, agency theory argues that both the CEOs' and directors' incentives need to be aligned with shareholders, by tying pay to performance and by providing managers and directors with equity based stakes in their firms. Corporate policy has widely followed this 
prescription. The share of variable performance pay in S\&P 500-firms amounts to about 75 percent of total compensation, mostly in the form of stocks and stock options (Murphy, 1999). In 2001, equity based pay constituted about two thirds of the median annual pay of US top executives, compared to zero in 1984 (Hall, 2003). In recent years, it has also become common practice to pay the board member at least in part according to the same principles (Stout, 2003). The idea is to bond managers' and directors' financial interests with those of the shareholders.

Despite its predominance, the agency model has proved to be seriously incomplete. There is no support for the agency-theory described relationship between equity ownership of CEOs and directors and firm performance (Dalton et al, 2003). Research has also failed to find significant proof of a link between executive pay and firm performance (Barkema \& Gomez-Mejia, 1998) ${ }^{1}$. Less than 5 percent of CEO pay seems to be explained by performance factors (Tosi et al., 2000). Pay for performance and equity based pay obviously do not lead to the expected alignment of the interests of managers with those of shareholders. On the contrary, experience in recent years has shown that, by linking salaries to stock options, performance pay led to an explosion of compensations due to windfall profits (Hall \& Liebman, 1998). Even after the stock market boom ended, this trend has, in many cases, simply continued. Management compensation has often increased even more, despite the fact that share prices have plummeted (Klinger et al., 2002). This suggests that, in reality, the compensation of managers has little to do with performance.

There are two reasons for the missing link between compensation and performance. Firstly, managers are able to exert considerable control over the amount of money they get (Bertrand \& Mullainathan, 2001; Benz, Kucher \& Stutzer, 2002; Bebchuk \& Fried, 2003). To a considerable extent, CEO pay reflects managerial rent seeking behavior ${ }^{2}$ rather than efficient incentives. Bebchuk, Fried and Walker (2001) provide extensive empirical evidence, suggesting that managers have indeed substantial influence over their own compensation. Managers exploit the fact that the shareholders are uncertain what firm value maximization means in concrete terms.

\footnotetext{
${ }^{1}$ See Hall and Liebmann (1998). However, the link between pay for performance and performance of the firm stated here is due to the increase of stock options and the virtual nonexistence of indexed options. Thus, windfall profits during the stock market boom are included.

${ }^{2}$ The concept of rent seeking has been developed in Public Choice theory; see Tullock (1967). Surveys are provided in Buchanan, Tollison \& Tullock (1980), Tollison (1982) and Rowley, Tollison \& Tullock (1988).
} 
"Earning management" is achieved by producing short-term increases in share prices, or by repricing their stock options. Some managers even resorted to unlawfully misrepresenting their firms' accounts in order to raise their private incomes. Looking back, it is possible to state that agency theory has obviously neglected the possibility of managers distorting their own standards of performance: “... much of agency theory ... unrealistically assumes that earnings and stock prices cannot be manipulated. That is a major weakness of the theory ..." (Becht, Bolton \& Röell, 2002, p. 47). Managers and directors are able to manipulate the absolute, as well as the relative performance criteria. The main instrument used to manipulate the performance criteria is to include peers in lower-performing firms (Porac, Wade \& Pollock, 1999). The boards of directors have not been able to overcome these shortcomings. The shortcomings would get even worse if one followed the proposal by agency theorists to compensate board members according to equity based criteria. This would provide board members with the same incentives to manipulate performance standards as the management and might explain why equity compensation of board members is not positively associated with firm performance (Daily et al, 2003, Dalton et al, 2003), as agency theorists have claimed (Jensen, 1993).

The second reason for the missing link between CEO compensation and performance is that a firm's activities are characterized by intensive team production, which cannot be captured by an approach focusing on a nexus of contracts between individual principals and individual agents (Blair \& Stout, 1999). As will be argued in the next section, the surplus of working together in a team is due to interactions among team members where there is no clear principal and agent. The input of individual team members is largely unobservable and the output of the team cannot be attributed clearly to individual team members, either by their superiors or by the team members themselves. This makes individual pay for performance an inappropriate incentive.

\section{Team Production Approach}

The team production approach of corporate governance emphasizes the interaction among specialized team members as an important reason that teams are able to produce more than the sum of the individual inputs. However, team production among selfish team members is subject to three problems (Blair \& Stout, 1999): free riding, information asymmetry and underinvestment 
in firm specific resources. The solution to the first problem is to appoint one member of the team as principal with the obligation to monitor the agents' inputs, and the right to appropriate the residual outcome (Alchian \& Demsetz, 1972). This solution does not work if there are information asymmetries between the principal and the agents and if firm specific investments are needed that are not easily contractible. An important example is the acquirement of firm specific knowledge, in particular tacit knowledge (Osterloh \& Frey, 2000). Such investments may not be recoverable, except by successfully carrying out the project and sharing the joint output. Thus the team members make themselves vulnerable to each other. With the exception of small homogeneous groups, where team members are able to monitor each other, the danger of underinvestment in such resources arises among selfish team members. As a solution, it is suggested that the team members jointly agree to give up control over their firm specific inputs and the team production output and to cede this control to a neutral third party (Rajan \& Zingales, 1998). This solution proposes a rationale for a separation of ownership and labor whenever specialized teamwork is involved, and the team members wish to protect themselves from their own opportunistic inclinations.

An important characteristic of the neutral third party is not being involved in firm specific investments. The third party does not have its own interests at stake and can solve conflicts between the team members as an internal court of appeal. It is viewed as a substitute for explicit contracting in projects that are complex and unpredictable. In the team production approach, this third party function is to be performed by the board of directors as an impartial "mediating hierarchy". The board enjoys a substantial range of discretion and acts as fiduciary for the firms' stakeholders (Blair \& Stout, 1999) ${ }^{3}$. The fiduciary role presupposes that the board members act as trustworthy mediators, comparable to judges or referees. They control and reward the managers. In the team production approach, managers', as well as directors', compensation can be linked to variable pay for performance criteria. Managers can be paid according to high-powered incentives, as long as the board acts as an impartial third party, though it remains unclear which

\footnotetext{
${ }^{3}$ Blair and Stout $(1999,2001 \mathrm{a}, 2001 \mathrm{~b})$ argue that directors' responsibility is not exclusive to shareholders' value maximization. Rather, they are charged with balancing the sometimes competing interests of a variety of stakeholders which have undertaken firm specific investments.
} 
criteria for incentive pay should be applied ${ }^{4}$. Board members can be compensated according to the joint team output, as long as their compensation is unrelated to firm specific investments.

Taking recourse to the board as a neutral third party to solve the team problems discussed is faced with shortcomings. Firstly, boards, as impartial mediators, should consist mainly of outside directors. However, empirical evidence demonstrates that there is no statistical correlation between the share of outside directors and financial performance (Dalton et al, 1998; Bhagat \& Black, 2002). The critical point is that the team production approach concentrates on the function of monitoring and mediating. It disregards the function of supporting the firm with firm specific resources, like firm specific human and relational capital (Baysinger \& Hoskisson, 1990; Hillman \& Dalziel, 2003). However, firm specific resources are not available without firm specific investments. The function of providing firm specific resources conflicts with the mediating and monitoring function of a "mediating hierarch". Secondly, managers themselves have to fulfill a mediating role with respect to the many teams existing in the firm. Empirical evidence shows that communicating and mediating are in fact the most time-consuming activities of managers. (e.g. Mintzberg, 1980). According to the team production model, managers should not invest in their specific resources vis-à-vis teams. The team production approach of corporate governance, as developed by Blair and Stout (1999), does not really solve the dilemma specialized teams are faced with: the dilemma between the economic surplus gained by specialized investments, which at the same time cause information asymmetries.

The team production model, as discussed here, does not question the assumption by the traditional principal agent view that managers and directors should be compensated according to variable pay for performance. Nevertheless, as we will argue in the next section, this model gives important insights into how to deal with the problems identified.

\footnotetext{
${ }^{4}$ Blair and Stout (2001a, p. 421) simply assume that a board of directors would have enough understanding of the relative contributions made. In Blair and Stout (1999, p. 283), it is argued that the board has to make sure that each member receives a return over his or her opportunity costs. Beyond that minimum, the share of the surplus is determined by relative political power. But realizing opportunity costs is dependent on competitive markets. The more specialized the team members are, the less competitive markets work. Thus, the determination of minimum wages are themselves subject to monopoly power (Miller ,1992, p.33).
} 


\section{THE COMMON POOL APPROACH TO EXECUTIVE COMPENSATION}

The common pool approach shares with the team production approach the emphasis on firms as a nexus of firm specific investments rather than a nexus of individual contracts. It also shares the crucial insight that mediating fiduciaries are required to induce employees to make firm or team specific investments. In contrast to the team production approach, we firstly postulate a fiduciary role not only for the board at the top of the firm but also for the CEOs and other managers to encourage teams to efficiently work in the firms' interests. Secondly, to do their job, these fiduciaries cannot avoid making firm specific investments, especially investments in firm specific knowledge. Thirdly, we emphasize the role of prosocial intrinsic motivation of directors and managers ${ }^{5}$, which must be enabled and fostered by appropriate corporate governance structures. This requirement helps to overcome the conflict between the mediating role and the role of providing firm specific resources present in the team production approach.

In the common pool approach, as well as in the team production approach, corporate activities are characterized by a high degree of complex interdependencies (Thompson, 1967; Grandori, 2000, Langlois, 2002). Simon (1991, p. 33) makes this point very clear in his seminal paper on organizations and markets:

"In general, the greater the interdependence among various members of the organization, the more difficult it is to measure their separate contributions to the achievement of organizational goals. But of course, intense interdependence is precisely what makes it advantageous to organize people instead of depending wholly on market transactions."

Intensive interdependencies for selfish individuals create the three problems discussed above: the option to free ride, to exploit information asymmetries and to under-invest in firm specific resources. They can be summarized as a social dilemma within the firm. Thus, social dilemmas are at the heart of firms' activities, in contrast to competitive markets (Miller, 1992; Frey \& Osterloh, 2002). Social dilemmas arise if the actions of self-interested individuals do not lead to

\footnotetext{
${ }^{5}$ Blair and Stout (2000) discuss intensively the need for directors to have prosocial intrinsic motivation. But they do not consider that CEOs and managers are faced with similar situations.
} 
socially desirable common pools ${ }^{6}$. As has been widely discussed within the knowledge-based theory of the firm, the most important common pools in companies are accumulated organizational knowledge and organizational routines. For these common resources to become a sustainable, hard to imitate competitive advantage, they must be firm specific (e.g. Grant, 1996; Kogut \& Zander, 1996; Nonaka \& Takeuchi, 1995; Spender, 1996). Directors and managers must make such investments in firm specific pool resources in order to reap these competitive advantages. Thus, third parties undertaking no such investments cannot solve the dilemma.

Today, after the occurrence of so many corporate scandals, corporate virtue has proved to be another crucial common pool resource in the firm. Dishonest behavior was by no means restricted to the top echelon, but filtered down through many layers within the corporation (Spector, 2003). Corporate virtue entails a generally shared notion of what business honesty is about. It originates from a sufficient number of persons with prosocial preferences who are prepared to not only behave honestly themselves but to contribute to observing norms of honesty by sanctioning the norm violators. Reprimanding norm violators in order to enforce the code of honesty (e.g. by whistle blowing) entails psychological costs, because colleagues usually tend to avoid open conflict. It is itself a common good that constitutes a social dilemma of a higher order: "Punishment almost invariably is costly to the punisher, while the benefits from punishment are diffusely distributed over all members. It is, in fact, a public good" (Elster, 1989, p. 41).

First and second order social dilemmas can be solved if the good of the community enters into the preferences of the individual, therewith becoming prosocial preferences. The social dilemma is turned into a coordination game, where defection is no longer the dominant solution (Sen, 1974). Thus, team production problems and corporate scandals have the same origins: a lack of prosocial preferences among directors and managers, which in turn cause social dilemmas. Efforts to solve these social dilemmas by offering individual pay for performance incentives are doomed to failure in the case of intensive interdependencies.

\footnotetext{
${ }^{6}$ This kind of conflict between individual and collective rationality is modeled in the prisoners' dilemma game (e.g. Dawes, 1980).
} 
Under such circumstances, high-powered incentives for CEOs and directors import market failures into the firm in a twofold manner. Firstly, markets fail to provide common goods because of contractual externalities. In a similar way, high-powered incentives in firms undermine the provision of firm specific common goods (e.g. Vining, 2003). This is the reason why even orthodox economists, who believe in the homo oeconomicus, reach the conclusion: "The use of low-powered incentives within the firm, although sometimes lamented as one of the major disadvantages of internal organization, is also an important vehicle for inspiring cooperation and coordination" (Holmström \& Milgrom, 1994, p. 989; see also Gibbons, 1998; Holmström, 1999). Secondly, there is a second kind of market failure, which is usually not considered by economists: Preferences are not given, but shaped by markets (Bowles, 1998). Self-serving behavior is influenced by the organizational environment (Davis, Schoorman \& Donaldson, 1997), thus reflecting the theories of their designers (Ghoshal \& Moran, 1996; Ferraro, Pfeffer \& Sutton, in press; Lane, Canella \& Lubatkin, 1999; Sundaramurtha \& Lewis, 2003). As a consequence, highpowered incentives aggravate the problem.

In the following two sections, we first show in detail that prosocial preferences are empirically more prevalent than standard economic theory assumes. Secondly, we demonstrate empirical evidence that prosocial preferences can be undermined or strengthened by institutional conditions.

\section{INTRINSICALLY MOTIVATED PROSOCIAL BEHAVIOR}

Prosocial preferences are a special case of intrinsic motivation. In the case of intrinsic motivation, an activity or its outcome is valued for its own sake and is self-sustained (Calder \& Staw, 1975, p. 599; Deci, 1975, p. 105). The work content itself produces direct satisfaction or utility without any compensation. ${ }^{7}$ In contrast, extrinsic motivation works through indirect satisfaction of needs,

\footnotetext{
${ }^{7}$ In economics, with the exception of Frey (1997), and more recently Benabou and Tirole (2002) and Sliwka (2003), only a few authors deal with intrinsic motivation as an endogenous phenomenon. Some economists admit the existence of intrinsic motivation, but then put it aside because it is difficult to analyze and control (e.g. Williamson, 1975), even if they agree that the assumption of solely extrinsically motivated people is an "extreme caricature" (Milgrom \& Roberts 1992, p. 42).
} 
most importantly through monetary compensation. This kind of motivation dominates in conventional economics, as is the case in the principal agent approach.

It is important to see that not all intrinsic motivation is prosocial. It only applies to obligationbased intrinsic motivation ${ }^{8}$, which was introduced into economics by Frey (1997) as an important form of incentive. It is crucial for the existence of corporate virtue and the loyalty required by fiduciaries.

A wealth of empirical evidence demonstrates that many people are indeed prepared to contribute to the common good of their company and community (Frey \& Meier, 2002). Important instances can be found both in the public sphere (tax morale and environmental ethics, see Frey, 1997) and in the business sphere. In business, three major instances have been discussed in the literature:

1. Voluntary rule following. People are prepared to follow rules and regulations that limit their self-interests without sanctions as long as they accept their legitimacy (Tyler, 1999, Tyler \& Blader, 2000). This supports the arguments of Max Weber (1978) that legitimacy is a property that is not only instrumental but reflects a social value orientation towards authority.

2. Extra-role behavior. According to research in "Organizational Citizenship Behavior", employees do not only observe rules voluntarily, but exert proactive behavior on behalf of the organization. They provide voluntary inputs, going far beyond the duties stipulated in their employment contracts (Organ, 1988; Organ \& Ryan, 1995). "Extra-role behavior" is thought of as a "willingness to cooperate", and accounts for the relatively low amount of free riding in organizations, compared to what orthodox economists would expect (Simon, 1991). Of particular interest,with respect to the solution of social dilemmas, are helping behavior, organizational compliance and corporate virtue, which all include sacrificing individual interests for the sake of the whole organization.

\footnotetext{
8 The other form (see Lindenberg, 2001) is enjoyment-based intrinsic motivation, referring to a satisfying flow of activity (e.g. Csikszentmihalyi, 1975), such as playing a game or reading a novel for pleasure. This is the incentive focused on by Deci and his group (Deci, Koestner \& Ryan, 1999).
} 
3. Open source software production. In one of the most innovative industries, software production, a very successful form of so-called open source software production has become a serious competitor to Microsoft. Software, like Linux, is produced voluntarily as a common good. This is done to a large extent without any monetary compensation and private property. Instead, this production is largely based on a gift relationship (Raymond, 2000; Osterloh, Rota \& Kuster, 2003).

Laboratory experiments have also revealed that a large number of people voluntarily contribute to public goods (see the surveys by Rabin, 1998; Ostrom, 1998, Fehr \& Fischbacher, 2003). The most extensively discussed experiments are the public good game and the ultimatum game.

1. Public good game. According to standard economics, people do not contribute to public goods; rational actors free ride on the contributions of others. However, when people trust others to contribute to a common good, they are also prepared to do so. Suppose that subjects A and B are endowed with a certain amount of money, e.g. 10 dollars. They have to decide how much they want to donate to a common pool. They are also told that any money donated will be doubled and then redistributed equally to the subjects. If both keep what they got, each earns 10 dollars. If both transfer their whole endowment, each earns 20 dollars. This setting resembles team production, where cooperation leads to a surplus. If both actors are selfish, they donate nothing, regardless of how much they expect the other subject to give. Despite the incentive to cheat, people typically contribute about 50 percent of their initial stake in experiments (e. g. Sally, 1995).

2. Ultimatum game. This game reveals that a sizeable number of people are willing to punish unfair behavior at a cost to themselves. Two persons have to agree on the division of a fixed sum of money given to a proposer. The proposer can make a proposal how to divide the money. If the responder rejects, both receive nothing. In the case of the responder accepting, the proposal is implemented. Rejection can be viewed as punishment for the violation of a social norm of fairness which comes at a price for the responder (Güth et al., 1982). In experiments, responders typically reject shares below 25 percent. Again, considerable variability across different cultures has been found (Henrich 
et al., 2001). This setting resembles the situation where a whistleblower in a "fraud firm" discloses malpractices of his or her boss at the cost of being punished or thrown out.

There are large and consistent deviations from the predictions of standard economics concerning "homo oeconomicus". People are prepared to behave in a prosocial way. However, prosocial behavior varies considerably across cultures and experimental settings. Thus, prosocial behavior is to a large extent dependent on social and economic factors. If the variables that promote or discourage prosocial behavior are understood, the first and second order social dilemmas in the firm can be overcome.

\section{HOW INSTITUTIONAL FACTORS DESTROY OR SUPPORT INTRINSICALLY MOTIVATED PROSOCIAL BEHAVIOR}

Several institutional factors can influence intrinsically motivated prosocial behavior (for an overview, see Bowles, 1998). The effects can be subdivided into a crowding-out and a crowdingin effect. We discuss each of these effects in turn.

\section{Crowding-out Effect}

A crowding-out effect is treated in two theories, self-determination theory and the theory of conditional cooperation.

\section{Self-determination theory}

According to self-determination theory (Deci \& Ryan, 1985; Deci \& Ryan, 2000), crowding-out takes place when perceived self-determination suffers from external interventions in the form of monetary incentives or control. As a result, individuals shift their "locus of causality" from inside to outside. Their attention shifts from the activity itself to the reward or sanction. The content of 
the activity loses its importance. A pre-condition for crowding-out to occur is that the individuals concerned have intrinsic motivation, which can then be undermined ${ }^{9}$.

There is much empirical evidence supporting this conclusion (for a comprehensive overview of empirical evidence, see Frey \& Jegen, 2001). It is impossible to summarize the results here of the large number of laboratory experiments on the crowding effect. Fortunately, no less than five formal meta-analytical studies of crowding theory are available. Rummel and Feinberg (1988) carried out 45 experimental studies from 1971 to 1985; Wiersma (1992) carried out 20 studies from 1971 to 1990; and Tang and Hall (1995) carried out 50 studies from 1972 to 1992. These meta-analyses essentially support the findings that intrinsic motivation is undermined. ${ }^{10}$ Deci, Koestner and Ryan (1999) conducted an extensive meta-analysis. The 68 experiments reported in 59 articles span the period from 1971 to 1997 , and refer to 97 experimental effects. It turns out that tangible rewards undermine intrinsic motivation for interesting tasks (i.e. tasks in which the experimental subjects show an intrinsic interest) in a highly significant and very reliable way. Such undermining is particularly true for monetary compensation. The crowding-out effect is stronger with monetary than with symbolic rewards. The crowding-out effect is also larger with expected than with unexpected rewards. When the problems in question are complicated, the negative relationship between reward and performance is stronger than when the problems are simple (see Deci \& Ryan, 1985; Heckhausen, 1991, ch. 15). In all cases, the behavior was initially perceived to be interesting and therefore intrinsically rewarding.

These laboratory experiments consider the effects of external interventions on enjoyment-based intrinsic motivation. But there are also numerous field and laboratory studies focusing on obligation-based motivation, such as contributing to a common good.

- Blood donation: Paying donors for donating blood undermines their intrinsic motivation to do so free of charge. Though it is difficult to isolate the many different influences on blood supply,

\footnotetext{
${ }^{9}$ In situations where no intrinsic motivation exists in the first place, monetary rewards can increase performance, like the simple job of working on an assembly line, see e.g. Lazear (1999).

${ }^{10}$ This view was challenged by Cameron and Pierce (1994) and Eisenberger and Cameron (1996), who concluded that the undermining effect is largely "a myth" on the basis of their own meta-analysis of studies published in the period 1971 to 1991. Deci, Koestner and Ryan (1999) conducted an extensive study to show that these conclusions are unwarranted and that the crowding-out effect is a robust phenomenon under specified conditions.
} 
in countries where most of the blood is supplied free of charge, paying for blood is likely to reduce total supply (Titmuss, 1970; Upton, 1973).

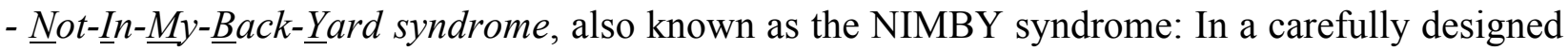
survey for a community located in central Switzerland, more than half the respondents $(50.8$ percent) agreed to have a nuclear waste repository built in their community. When compensation (in monetary terms) was offered, the level of acceptance dropped to 24.6 percent (Frey \& Oberholzer-Gee, 1997; Frey, Oberholzer-Gee \& Eichenberger, 1996).

- Environmental protection: Baumol and Oates (1979), Hahn (1989) and Kelman (1981) observed that, under certain conditions, the introduction of environmental charges has little effect. When the penalty for environmental pollution is perceived to be very controlling, people are no longer so motivated to protect the environment for intrinsic reasons.

- Social norms of good conduct: Gneezy and Rustichini (2000a) found in a field study that fining parents for picking up their children late from a childcare center had an adverse effect. The fine led to a significantly lower level of punctuality. When the fine was discontinued, punctuality remained at the lower level. Obviously the parents' obligation to norms of good conduct was undermined by the external monetary intervention.

- Labor contracts as "gift exchange": In an experiment with students, Irlenbusch and Sliwka (2003) compared two settings. In the first setting, "principals" offered a fixed amount of money and the "agents" chose an effort level. In the second setting, the principals had to make a choice between a fixed wage and an incentive scheme and then the agents chose their effort level. Efforts were higher in the first setting than in the case when piece rates were paid. Also, in the first setting, agents mentioned significantly more often the well-being of the principal than in the second setting. The social norm of reciprocity or partial gift exchange (Akerlof, 1982), which worked in the first setting, was crowded-out in the second setting (see also Fehr \& Gächter, 2002).

- Voluntary work: Stukas, Snyder and Clary (1999) show that voluntary contributions to unpaid helping activities are higher when external pressure is low. Frey and Götte (1999) found that the 
hours offered for work in the community field were lower when it was paid than when it was unpaid. Gneezy and Rustichini (2000b) analyzed the behavior of school children collecting money voluntarily, i.e. without monetary compensation (e.g. for cancer research or disabled children). The children reduced their efforts by about 36 percent when they were promised a bonus of one percent of the money collected. Their effort to collect for the good cause could be significantly raised when the bonus was increased from one to ten percent of the money collected, but they did not reach the initial collection level again.

This field experiment shows clearly that there are two countervailing forces affecting behavior: the first is the standard relative price effect, suggesting that an increase in payment increases effort. This is shown in Figure 1, which illustrates the well-known supply curve of work effort.

Figure 1

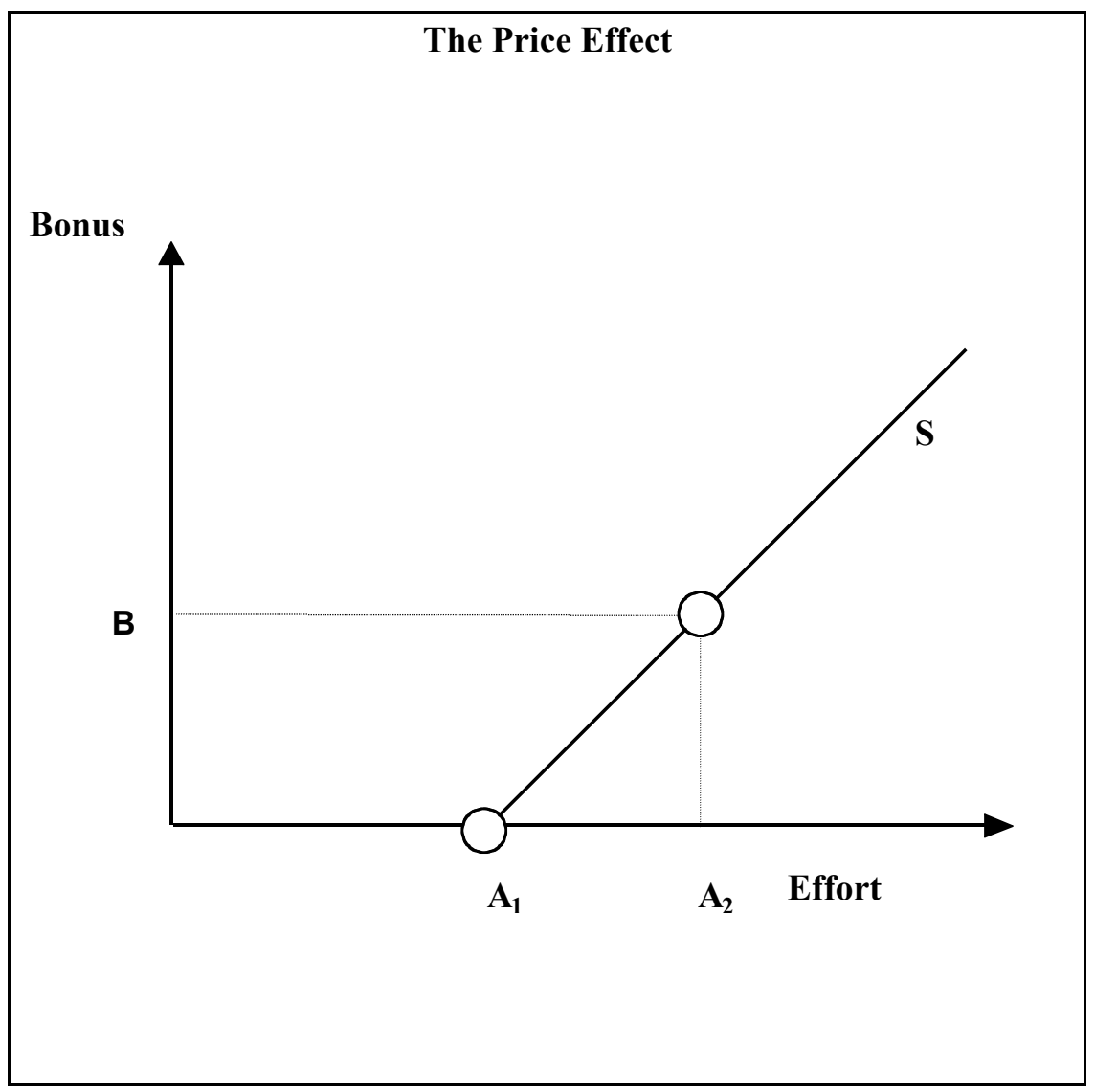


$\mathbf{A}_{1} \quad \mathbf{A}_{2} \quad$ Effort

With no bonus, children put in effort $\mathrm{A}_{1}$. Provided there is no crowding-out effect, a bonus with the value of $\mathrm{B}$ will increase their effort from $\mathrm{A}_{1}$ to $\mathrm{A}_{2}$. This is the pure price effect.

The second countervailing force affecting behavior is the crowding-out effect, suggesting that an increase in payment reduces effort ${ }^{11}$. Experimental and field studies suggest that children begin to lose interest as a result of the bonus. The supply curve shifts to the left from $\mathrm{S}$ to $\mathrm{S}^{\prime}$. As a result, children's efforts fall to $\mathrm{A}_{3}$. This is shown in Figure 2.

Figure 2

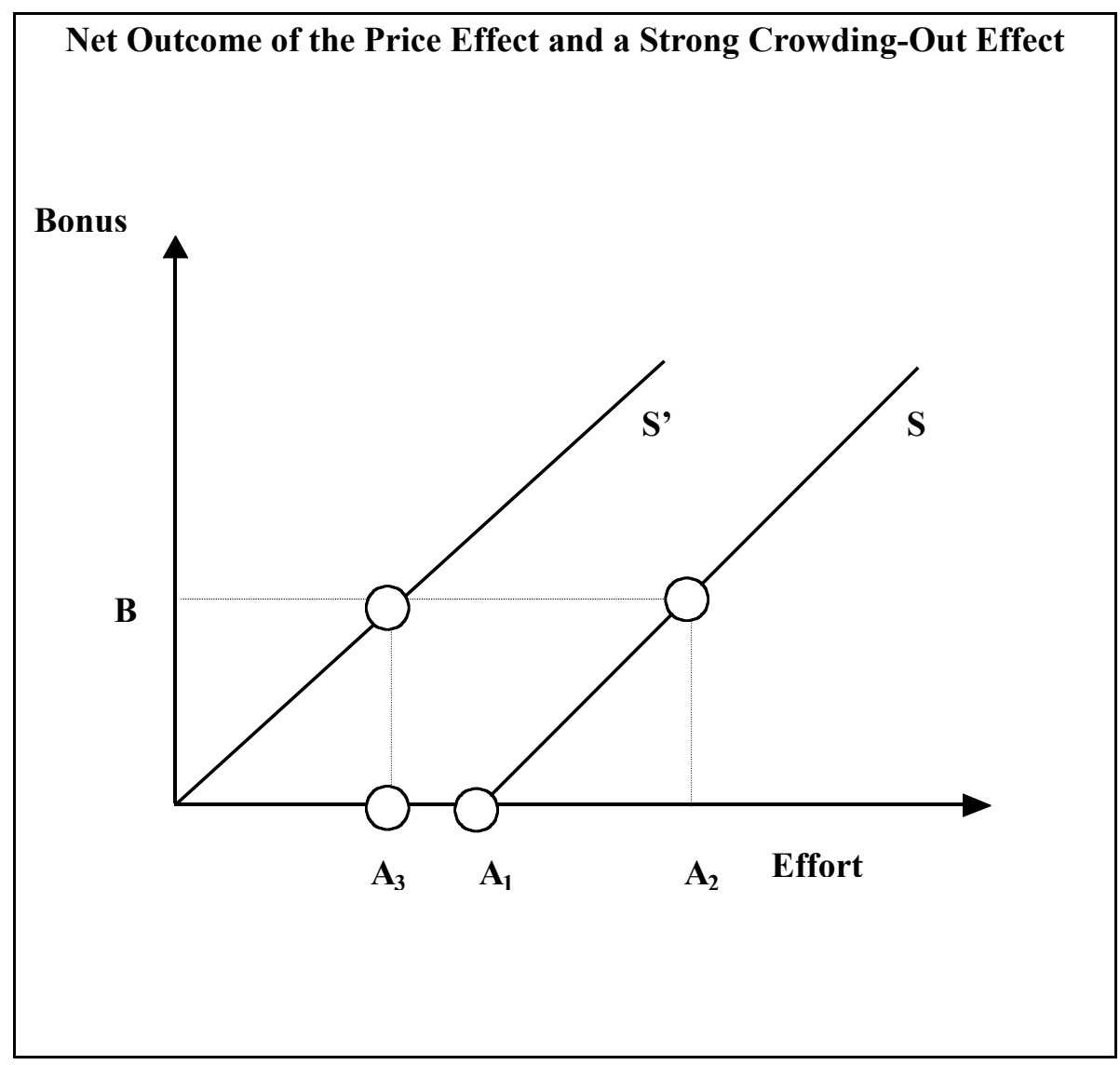

\footnotetext{
${ }^{11}$ Most studies compare situations with and without monetary compensation. However, the two studies by Frey \& Oberholzer (1997) and Gneezy \& Rusticini (2000b) found that an increase in compensation reduces individuals' obligation based motivation, resulting in lower voluntary contributions to collective goods.
} 
In this instance, the price effect from $A_{1}$ to $A_{2}$ is outweighed by the crowding-out effect from $A_{2}$ to $\mathrm{A}_{3}$. However, this need not necessarily be the case. As illustrated in Figure 3, it very much depends on the intensity of the crowding-out effect. On this occasion, the crowding-out effect shifts the supply curve for effort from $\mathrm{S}$ to $\mathrm{S}^{\prime \prime}$. The bonus now increases effort from $\mathrm{A}_{1}$ to $\mathrm{A}_{4}$.

Figure 3 represents the situation which occurred when the children were promised the much higher bonus of 10 percent.

Figure 3

\section{Net Outcome of the Price Effect and a Weak Crowding-Out Effect}

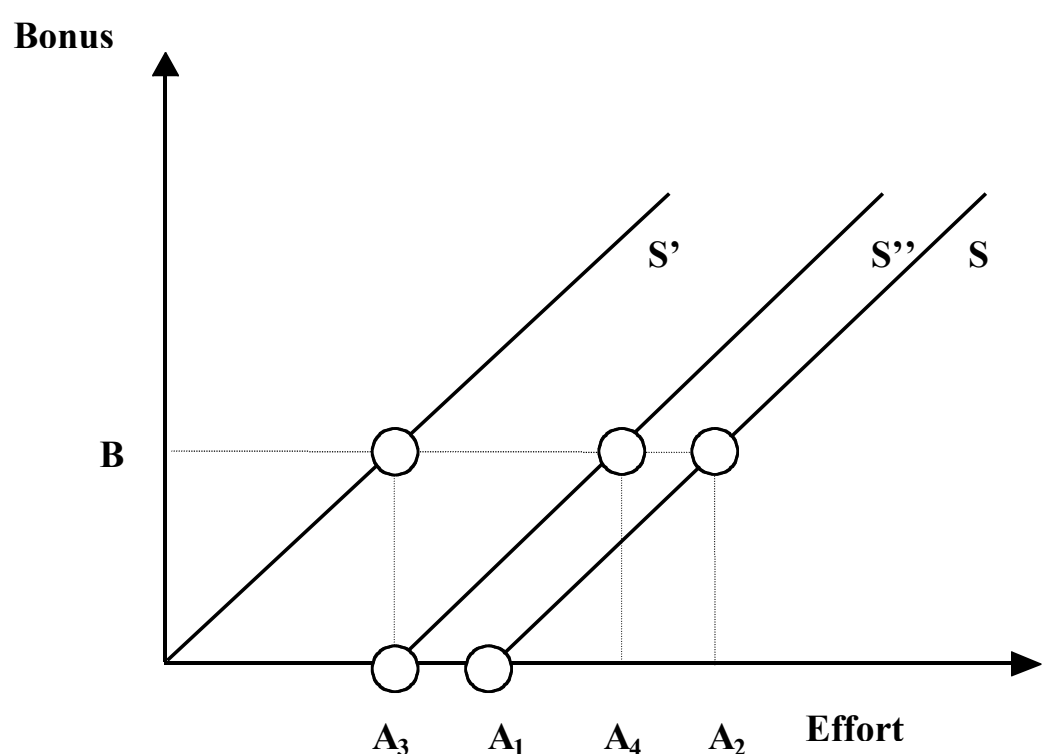


Thus, the crowding-out effect can be seen to counteract the price effect ${ }^{12}$. It is difficult to forecast whether the price or crowding-out effect will predominate in any particular case. However, self determination theory shows that strengthening monetary incentives comes at a high price compared to strengthening intrinsic motivation: on average, monetary incentives explain only 10 percent of the variance in performance, compared to 30 percent which are explained by obligation based intrinsic norms (Tyler \& Blader, 2000, p. 48, 62). A recently published review on different percentages of variable pay suggests that, on average, it is sufficient to pay a very small percentage of variable pay - as low as three percent of a person's total pay - to increase performance appreciably. Higher percentages did not affect performance on average. It appears that the actual amount of incentive pay as a proportion of fixed pay can be quite small and still be effective (Bucklin \& Dickinson, 2001). The factors influencing the relative strength of the crowding-out and relative price effect are specified in self-determination theory (Deci \& Ryan 2000, Frey 1997). Intrinsic motivation is affected negatively and strongly the more people feel that their autonomy, competence and social relatedness is curtailed. In particular, in cases where intrinsic motivation exists at the outset, variable pay for performance systems deteriorates the willingness to contribute voluntarily to the common good when the variable pay is perceived as controlling. Such contributions are essential in teamwork, when performance cannot be attributed to individuals (Osterloh \& Frey, 2000).

\section{Theory of conditional cooperation}

People contribute the more to common goods, the more they expect others to do so. They are conditional cooperators (Levi, 1988; Ostrom, 2000; Fischbacher, Gächter \& Fehr, 2001). On the other hand, many people are conditional defectors. As a consequence, prosocial intrinsic motivation deteriorates if too many people free ride. Employees' honesty is undermined if they observe that their superiors feather their own nests. They are no longer prepared to solve the first order social dilemma by e.g. investing in team firm specific knowledge. Nor do they contribute to the solution of the second order dilemma by whistle blowing or blaming colleagues who

\footnotetext{
${ }^{12}$ There is, however, one essential prerequisite: intrinsic motivation must have been present at the outset, otherwise there would be nothing to undermine. In the case of straightforward activities, for instance where intrinsic motivation is often scarce, there will be no discernible crowding-out effect.
} 
misbehave ${ }^{13}$. Equity-based compensations, as long as they are restricted to the top echelons, contradict what Hansmann (1980) calls the non-distribution constraint, which is a major precondition for voluntary donations to organizations: voluntary contributions cannot be redistributed among those in charge of the organization. Empirical evidence shows that making profit sharing not only available to managers, but to all employees, reduces the probability of crime in firms by 34 percent (Schnatterly, 2003). This indicates a greater commitment to corporate virtue if people do not feel exploited ${ }^{14}$. It helps to explain why entire firms, and not only the top management, were subject to all pervading greed and malpractice. Dishonest behavior was by no means restricted to top management, but filtered down through many layers within the corporation. With Enron, for instance, it was revealed that the whole board, including its president and vice-president, knew about the malpractices. It was also general knowledge among the firm's employees (Salter 2003).

\section{Crowding-in Effect}

A positive effect on intrinsic motivation of an institutional factor is called crowding-in. This effect has been less investigated than the crowding-out effect (but see Deci \& Ryan, 2000). Limited empirical evidence exists regarding compensation-related factors relevant for crowdingin.

- Instructions. People seem to be inclined to do what they are asked to do, especially when the suggestion comes from someone who is perceived as a legitimate authority. Instructions to cooperate in public good games raise the cooperation rate as much as 40 percent (Sally, 1995). In real life settings, it is shown that people adhere to laws (Tyler, 1990) and accept the decisions of authorities they believe to be legitimate (Tyler \& Huo, 2002), even if it is not in their self-interest to do so. In the last decade, agency theorists prompted managers and directors to think otherwise. Economics became dominant in social science (Ferraro, Pfeffer \& Sutton, in press). As a

\footnotetext{
${ }^{13}$ In multi-person public good games, the cooperation rate deteriorates sharply, depending on the size of the group, if altruistic punishment of defectors is not possible. It deteriorates less if altruistic punishment of defectors is possible. The least deterioration is realized if persons who are not prepared to punish others can themselves be punished; see Fehr and Fischbacher (2003).

${ }^{14}$ Profit-sharing does not crowd out intrinsic motiviation because it is taken as a matter of fair redistribution and not as a matter of individual control and reduction of self-determination.
} 
consequence, people overestimate the power of self-interest to affect the behavior of others, even when their own behavior was not primarily self-interested (Miller \& Ratner, 1998). This had an effect on the behavior of managers, as Paul Volker, the former Chairman of the Federal Reserve Board, confirmed: "Traditional norms didn't exist. You had this whole culture where the only sign of worth was how much money you made" (Cassidy, 2002).

- Framing of socially appropriate behavior. People are highly sensitive to signals about socially appropriate behavior. This became evident in a public good game. Players were divided into two groups. The first group was told they were going to play "the Wall Street Game". One third of the group cooperated. The second group was told that they were playing "the Community Game". More than two thirds cooperated (Liberman, Samuels \& Ross, 2003). Framing might also explain what happened in the field study on fining parents for picking up their children too late (Gneezy \& Rustichini, 2000a). Fining switched the frame from a normative frame to a gain frame (Lindenberg, 2003; Tenbrunsel \& Messick, 1999). The fine signaled that in the gain frame it was socially acceptable that parents arrive too late. As the already mentioned experiment of Irlenbusch and Sliwka (2003) shows, fixed pay enhances other regarding behavior in relation to the principal. To change a reward system from flat rates to incentive pay signals to managers and directors that doing one's duty without extra pay is not socially appropriate. In contrast, we expect them to behave as homines oeconomici. This signal could become a self-fulfilling prophecy (Stout, 2003, p. 16).

Personal contacts and incomplete contracts. Communication, or other conditions reducing social distance between persons, increases contribution in public good games (Ledyard, 1995; Dawes, van de Kragt \& Orbell, 1988; Frey \& Bohnet, 1995). Other regarding behavior is stronger in situations where contracts are incomplete compared to situations of more complete contracts (Kollock, 1994). These results might be summarized such that the less the situation approximates a competitive market, the more prosocial behavior will be observed. Anthropological field studies also provide examples for such changing behavior (Bowles, 1998, p. 899). The literature on psychological contracts also stresses that transactional contracts, including precise job descriptions, short time frames, no socio-emotional elements and individualized pay elicits less 
commitment to the firm than relational contracts, including the necessity to interact, long time frames, many socio-emotional elements and standardized pay (Rousseau, 1995, Kidder \& Buchholtz, 2002).

- Procedural fairness greatly impacts the willingness to contribute to common goods and to follow rules that are not in favor of one's own self-interest (Tyler \& Lind, 1992, Tyler \& Blader, 2003). The characteristics that lead to perceived procedural fairness can be summarized as participation, being treated with dignity, respect and neutrality. A precondition of neutrality is the belief that authorities do not allow their personal advantages and biases to enter into their decisions $^{15}$. Therefore politicians, public officials and judges receive fixed salaries to underpin their neutrality. Those persons who set the regulations should not be given an incentive to manipulate the corresponding criteria in their own favor (Frey, 2003). This is exactly what Max Weber (1978) believed to be essential for the efficiency of bureaucracy. In management, the exact opposite took place: the top executives were given the opportunity to manipulate the criteria by which they were evaluated and compensated. Under these circumstances, neutrality is hard to imagine. As a consequence, the team members at lower levels are not prepared to contribute to the first and second order common good.

- Avoiding the self-serving bias. There is strong empirical evidence that even honest people are subject to an unconscious "self-serving bias". In situations characterized by ambiguity or discretion, it is typical that managerial decision-making judgments of what is beneficial for others conflates with what one considers beneficial for oneself. Unlike conscious corruption, such conflation cannot be deterred by sanctions (Babcock \& Loewenstein, 1997; Bazerman, Loewenstein \& Moore, 2002). Instead, it can be reduced by lowering the incentives to take care of one's own interests. This can be achieved by attributing more importance to fixed wages for managers, as well as for board members. With respect to the self-serving bias, it is most important not to compensate the board members according to the same criteria (e.g. stock prices)

\footnotetext{
15 Experiments show that sanctions perceived as pro-socially motivated enhance cooperative behavior and rule following, whereas sanctions serving the punisher's self-interest crowd it out (Fehr \& Rockenbach2003).
} 
as the management, because the self-serving bias would unconsciously undermine the willingness to control.

Crowding-out and crowding-in effects of variable pay for managers and directors can have a considerable impact on firm performance. This does not speak against markets or pay for performance in general. When interdependencies between actors are simple and easily contractual, these institutional settings work efficiently. If this is not the case - and this is what makes it advantageous to organize such activities inside firms in the first place - market failures are imported into the firm.

\section{CONCLUSIONS}

Corporate governance systems based on agency theory as the dominant approach today are faced with widely publicized corporate scandals. But its proponents still believe in its basic message: The general idea of equity-based compensation provides managers and directors with desirable monetary incentives, but the system of pay for performance needs to be improved.

The present paper draws a different conclusion. High-powered incentive compensation, even if optimally designed, aggravates the problems in the corporate sector. Pay for performance gives managers and directors incentives to manipulate performance criteria and to resort to fraudulent accounts to the disadvantage of the long-term interests of the firm.

The firm should be looked at in terms of a bundle of common pool resources. This basically differs from agency theory's view of the firm as a nexus of individual contracts. Common pool resources are collective goods. They generate a joint surplus not attributable to single actors. It is essential that the production of such collective goods depends on prosocial intrinsic incentives. Agency theory assumes that managers' and directors' additional effort is solely motivated by extrinsic incentives. But individuals' motivations are more broadly based. Individuals derive utility from the activity itself or because they wish to comply to given normative standards for their own sake. The extent of such intrinsically motivated behaviour can be shaped and supported 
by appropriate institutions. High powered monetary incentives can have an impact on intrinsically motivated behavior in two ways. Firstly, they can crowd out the intrinsic motivation of managers by shifting their interest from the activity itself to the reward. Secondly, they can hinder crowding in or raising intrinsic motivation in several ways. Variable pay for performance:

- gives a signal to managers that doing one's duty without extra pay is socially inappropriate.

- $\quad$ approximates within the firm the conditions of a competitive market in which prosocial behavior is inadequate.

- changes relational contracts into transactional contracts, which include less socioemotional elements.

- $\quad$ undermines the neutrality of superiors, therewith reducing perceived procedural fairness.

- $\quad$ enlarges the self-serving bias of managers and directors.

The paper does not argue that there is no relative price effect going with variable pay for performance. A higher salary does raise the extrinsic incentives for work. But we show that there is a countervailing effect, leading a higher salary to crowd out the intrinsic motivation for work. We demonstrate, based on much empirical evidence, that the net effect in the case of common goods tends to be negative, favoring disfunctional behavior in the firm.

\section{REFERENCES}

Akerlof, G.A. 1982. Labor Contracts as Partial Gift Exchange. Quarterly Journal of Economics, 84, 488-500.

Alchian, A.A. \& Demsetz, H. (1972). Production, Information Costs and Economic Organization, American Economic Review, 62 (December), 777-795.

Babcock, L. \& Loewenstein, G. (1997). Explaining Bargaining Impasse: The Role of Self-Serving Biases. Journal of Economic Perspectives, 11 (1), 109-126.

Barkema, H.G. \& Gomez-Mejia, L.R. (1998). Managerial compensation and firm performance: A general research framework. Academy of Management Journal, 41, 2, 135-145.

Baumol, W.J. \& Oates, W.E. (1979). Economics, Environmental Policy, and the Quality of Life. Englewood Cliffs: Prentice-Hall. 
Baysinger, B. \& Hoskisson, R. (1990). The Composition of Boards of Directors and Strategic Control. Academy of Management Review. 15, $72-87$.

Bazerman, M.H., Loewenstein, G. \& Moore, D.A. (2002). Why Good Accountants Do Bad Audits. Harvard Business Review, November 2002, 97-102.

Bebchuk, L.A. \&. Fried, J.M. (2003). Executive Compensation as an Agency Problem. Working Paper No. 421, John Ohlin Center for Law, Economics and Business, Harvard University.

Bebchuk, L.A., Fried J.M. \& Walker, D.I. (2001). Executive Compensation in America: Optimal Contracting for Extraction of Rents? NBER Working Paper 8611.

Becht, M., Bolton, P. \& Röell, A. (2002). Corporate Governance and Corporate Control. ECGI Working Paper Series in Finance 02/2002, 30 September 2002. Also in G. Constantinides, H. Milton \& R. Stulz (Eds.), Handbook of Finance, North Holland.

Benabou, R. \& Tirole, J. (2002). Intrinsic and Extrinsic Motivation. Working Paper, Princeton University. http://www.princeton.edu/ rbenabou/Intrinsic2.pdf

Benz, M., Kucher, M. \& Stutzer, A. (2002). Stock Options for Top Managers - The Possibilities and Limitations of a Motivational Tool. In B.S. Frey and M. Osterloh (Eds.) Successful Management by Motivation. Balancing Intrinsic and Extrinsic Incentives, 89-118. Berlin, Heidelberg, New York: Springer.

Bertrand, M. \& Mullainathan, S. (2001). Are CEOs Rewarded for Luck? The Ones without Principals Are. The Quarterly Journal of Economics. 116, 901-932.

Bhagat, S. \& Black, B. (2002). The Non-Correlation Between Board Independence and Long-Term Firm Performance. Journal of Corporation Law 27, 231-273.

Black, B.S. (1992). Agents watching agents: The Promise of institutional investors voice. UCLA Law Review, 39, 811-893.

Blair, M. \& Stout, L.A. (1999). A Team Production Theory of Corporate Law. Virginia Law Review, No. 85, 2, 246-328.

Blair, M. \& Stout, L.A. (2001a). Director Accountability and the Mediating Role of the Corporate Board. Washington University Law Quarterly, 79 (2), 403-449.

Blair, M. \& Stout, L.A. (2001b). Trust, Trustworthiness and the Behavioral Foundations of Corporate Law. University of Pennsylvania Law Review 149 (6) June 2001, 1735-1810.

Bowles, S. (1998). Endogenous Preferences: The Cultural Consequences of Markets and other Economic Institutions. Journal of Economic Literature, 36, 75-111.

Buchanan, J.M, Tollison, R.D. and G. Tullock (eds) (1980). Towards a Theory of the Rent-Seeking Society. College Station: Texas A\&M Press.

Bucklin, B.R. \& Dickinson, A.M. (2001). Individual Monetary Incentives: A Review of Different Types of Arrangements Between Performance and Pay. Journal of Organizational Behavior Management, 21 (3), 45-137.

Calder, B.J. \& Staw, B.M. (1975), The Self-Perception of Intrinsic and Extrinsic Motivation, Journal of Personality and Social Psychology, 31, 599-605. 
Cameron, J. \& Pierce, W.D. (1994). Reinforcement, Reward, and Intrinsic Motivation: A MetaAnalysis. Review of Educational Research, 64 (Fall), 363-423.

Cassidy, J. (2002). The Greed Cycle: How the Financial System Encouraged Corporations to Go Crazy. The New Yorker, September 23, 2002.

Csikszentmihalyi, M. (1975). Beyond Boredom and Anxiety. San Francisco: Jossey-Bass.

Daily, Ch., Dalton, D.R. \& Canella, A.A. (2003). Corporate Governance: Decades of Dialogue and Data. The Academy of Management Review, 28 (3), 371-382.

Dalton, D.R., Daily, C.M., Ellstrand, A.E. \& Johnson, J.L. (1998). Meta-analytic reviews of board composition, leadership structure, and financial performance. Strategic Management Journal, 19, 269-290.

Dalton, D.R., Daily, C.M., Certo, S.T. \& Roengpitya, R. (2003). Meta-analyses of Financial Performance and Equity: Fusion or Confusion? Academy of Management Journal, 46, 13-26.

Davis, J.D., Schoorman, F.D. \& Donaldson, L. (1997). Towards a Stewardship Theory of Management, Academy of Management Review, 22 (1), 20-47.

Dawes, R.M. (1980). Social Dilemmas. Annual Review of Psychology, 31, 169-193.

Dawes, R.M., van de Kragt, A.J.C. \& Orbell, J.M. (1988). Not Me or Thee But We: The Importance of Group Identity in Eliciting Cooperation in Dilemma Situations-Experimental Manipulations, Acta Psychologica, 68, 83-97.

DeCharms, R. (1968). Personal Causation: The Internal Affective Determinants of Behavior. New York: Academic Press.

Deci, E.L. (1975). Intrinsic Motivation. New York: Plenum Press.

Deci, E.L., Koestner, R. \& Ryan, R.M. (1999). Meta-Analytic Review of Experiments: Examining the Effects of Extrinsic Rewards on Intrinsic Motivation. Psychological Bulletin, 125, 627-668.

Deci, E.L. \& Ryan, R.M. (1985). Intrinsic Motivation and Self-Determination in Human Behavior. New York: Plenum Press.

Deci, E.L. \& Ryan, R.M. (2000). The "What" and "Why" of Goal Pursuits: Human Needs and the SelfDetermination of Behavior. Psychological Inquiry, 11 (4), 227-268.

Eisenberger, R. \& Cameron, J. (1996). Detrimental Effects of Reward: Reality or Myth? American Psychologist, 51, 1153-1166.

Elster, J. (1989), The Cement of Society: A Study of Social Order, New York, NY, Cambridge University Press.

Fehr, E. \& Fischbacher, B. (2003). The nature of human altruism. Nature, 425, 23 Oct., 785-791.

Fehr, E. \& Gächter, S. (2002). Do Incentive Contracts Crowd out Voluntary Cooperation? Working paper No. 34, Institute for Empirical Research in Economics, University of Zurich.

Fehr, E. \& Rockenbach, B. (2003). Detrimental Effects of Sanctions on Human Altruism. Nature, 422 (13) March 2003, 137-140. 
Ferraro, F., Pfeffer, J. \& Sutton, R. (in press). Economics Language and Assumptions: How Theories can become Self-Fulfilling. Academy of Management Review.

Fischbacher, U., Gächter, S. \& Fehr, E. (2001). Are People Conditionally Cooperative? Evidence from Public Good Experiments. Economic Letters, 71, 397-404.

Frey, B.S. (1997). Not Just For the Money: An Economic Theory of Personal Motivation. Brookfield: Edward Elgar.

Frey, B.S. (2003). Corporate Governance: What Can We Learn from Public Governance? Working Paper, Institute for Empirical Economic Research, University of Zurich.

Frey, B.S. \& Bohnet, I. (1995). Institutions Affect Fairness: Experimental Investigations. Journal of Institutional and Theoretical Economics, 151, 2, 286-303.

Frey, B.S., \& Götte, L. (1999). Does Pay Motivate Volunteers? Institute for Empirical Research in Economics, University of Zürich, Working Paper No.9.

Frey, B.S. \& Jegen, R. (2001). Motivation Crowding Theory: A Survey of Empirical Evidence. Journal of Economic Surveys, 15 (5), 589-611.

Frey, B.S. \& Meier, S. (2002). Pro-Social Behavior, Reciprocity or Both? Working Paper Series (107), Institute for Empirical Economic Research, University of Zurich. http://www.unizh.ch/iew/wp/iewwp107.pdf

Frey, B.S. \& Oberholzer-Gee, F. (1997). The Cost of Price Incentives: An Empirical Analysis of Motivation Crowding-out. American Economic Review, 87 (September), 746-755.

Frey, B.S., Oberholzer-Gee, F. \& Eichenberger, R. (1996). The Old Lady Visits Your Backyard: A Tale of Morals and Markets. Journal of Political Economy, 104 (6), 193-209.

Frey, B.S. \& Osterloh, M. (2002). Successful Management by Motivation. Balancing Intrinsic and Extrinsic Incentives. Berlin, Heidelberg, New York: Springer.

Fuller, J. \& Jensen, M. (2002). Just Say No to Wall Street. Putting a Stop to the Earnings Game. Journal of Applied Corporate Finance, Winter 2002, 41-46.

GAO 2002 Financial Statement Restatements: Trends, Market Impacts, Regulatory Responses, and Remaining Challenges. GAO-03-138. General Accounting Office: Washington DC.

Ghoshal, S. \& Moran, P. (1996). Bad for Practice: A Critique of the Transaction Cost Theory, Academy of Management Review, 21, 1, 13-47.

Gibbons, R. (1998). Incentives in Organizations. The Journal of Economic Perspectives, 12, 4, 115-132.

Gneezy, U. \& Rustichini, A. (2000a). A Fine Is a Price. Journal of Legal Studies, 29, 1-18.

Gneezy, U. \& Rustichini, A. (2000b). Pay Enough or Don't Pay at All. Quarterly Journal of Economics, $115(2), 791-810$.

Grandori, A. (2000). Organization and Economic Behavior. London: Routledge.

Grant, R.M. (1996). Towards a Knowledge-based Theory of the Firm. Strategic Management Journal, 17 (Winter Special Issue), 109-122. 
Güth, W, Schmittberger, R. \& Schwarze, B. (1982). An Experimental Analysis of Ultimatum Bargaining. Journal of Economic Behavior and Organization, 3, 367-388.

Hahn, R.W. (1989). Economic Prescriptions for Environmental Problems: How the Patient Followed the Doctor's Orders. Journal of Economic Perspectives, 3, 9-114.

Hall, B.J. (2003). Six Challenges in Designing Equity-Based Pay. Journal of Applied Corporate Finance 15(3), 21-33.

Hall, B.J. \& Liebman, J.B. (1998). Are CEOs Really Paid Like Bureaucrats? Quarterly Journal of Economics 113, 653-691.

Hansmann, H.B. (1980). The Role of Nonprofit Enterprise. Yale Law Journal, 89, 835-901.

Harris, J. \& Bromiley, P. (2004). Incentives to Cheat: the Influence of CEO Incentive Compensation and Relative Firm Performance on Financial Misrepresentation. Mimeo Carlson School of Management, University of Minnesota.

Heckhausen, H. (1991). Motivation and Action. Berlin, Heidelberg, New York: Springer.

Hegele, C. \& Kieser, A. (2001). Control the Construction of Your Legend or Someone Else Will. Journal of Management Inquiry, 10: 298-309.

Henrich, J., Boyd, R., Bowles, S., Camerer, C., Fehr, E., Gintis, H. \& McElreath, R. (2001). In Search of Homo Economicus. Behavioral Experiments in 15 Small-Scale Societies. American Economic Review (Papers and Proceedings), 91, 73-78.

Hillman, A.J., \& Dalziel, Th. (2003). Boards of Directors and Firm Performance: Integrating Agency and Resource Dependence Perspectives. The Academy of Management Review, 28, 383-396.

Holmström, B. (1999). The Firm as a Subeconomy. Journal of Law, Economics, and Organization, 15,1: 74-102.

Holmström, B. \& Milgrom, P. (1994). The Firm as an Incentive System. American Economic Review, 84, 972-991.

Irlenbusch, B. \& Sliwka, D. (2003). Incentives, Decision Frames and Motivation Crowding Out - An Experimental Investigation. Working Paper, University of Bonn.

Jensen, M.C. (1993). The modern industrial revolution, exit, and the failure of internal control systems. Journal of Finance, 48, 831-880.

Jensen, M.C. \& Murphy, K.J. (1990). CEO Incentives - It's Not How Much You Pay, But How. Harvard Business Review (May-June), 138-153.

Johnson, S.A., Ryan, H.E. Jr. \& Tian, Y.S. (2003). Executive Compensation and Corporate Fraud. Working Paper E.J. Ourso College of Business Administration, Louisiana State University.

Kelman, S. (1981). What Price Incentives? Economists and the Environment. Boston: Auburn House.

Kidder, D.L. \& Buchholtz, A.K. (2002). Can Excess Bring Success? CEO Compensation and the Psychological Contract. Human Resource Management Review 12, 599-617. 
Klinger, S., Hartmann, Ch., Anderson, S., Cavagh, J. \& Sklar, H. (2002): Executive Excess 2002. CEOs Cook the Books, Skewer the Rest of Us. Institute for Policy Studies and United for a fair Economy, http://www.FairEconomy.org

Kogut, B. \& Zander, U. (1996). What Firms Do? Coordination, Identity, and Learning. Organization Science, 7, 502-518.

Kollock, P. (1994). The Emergence of Exchange Structures: An Experimental Study of Uncertainty, Commitment, and Trust. American Journal of Sociology, 100, 313-345.

Lambert, R.A., Lanen, W.N. \& Larcker, D.F. (1989). Executive Stock Option Plans and Corporate Dividend Policy. Journal of Financial and Quantitative Analysis, 24, 409-425.

Lane, P.J., Canella, A.A., \& Lubatkin, M.H. (1999). Ownership Structure and Corporate Strategy: One Question Viewed from Two Different Worlds. Strategic Management Journal, 20, 1077-1086.

Langlois, R.N. (2002). Modularity in Technology and Organizations. Journal of Economic Behavior \& Organization, 49, 19-37.

Lazear, E. (1999). Personnel Economics: Past Lessons and Future Directions. Journal of Labor Economics, 17, 199-236.

Ledyard, J.O. (1995). Public goods: A Survey of Experimental Research. In: Kagel, J. \& Roth, A.E. (Ed.) Handbook of Experimental Economics. Princeton: Princeton University Press, 111-194.

Levi, M. (1988). Of Rule and Revenue. Berkeley: University of California Press.

Liberman, V., Samuels, S. \& Ross, L. (2003). The Name of the Game: Predictive Power or Reputation vs. Situational Labels in Determining Prisoners' Dilemma Game Moves. Working Paper, Department of Psychology, Stanford University, Stanford, CA.

Lindenberg, S. (1984). Preferences versus Constraints. Zeitschrift für die gesamte Staatswissenschaft, 140: $96-103$.

Lindenberg, S. (2001). Intrinsic Motivation in a New Light. Kyklos, 54: 317-343.

Lindenberg, S. (2003). The Cognitive Side of Governance. In: V. Buskens, W. Raub and Ch. Snijders (Eds), The Governance of Relations in Markets and Organizations. Research in the Sociology of Organizations, Vol. 20, 47-76.

Milgrom, P.R. \& Roberts, J. (1992). Economics, Organization and Management. New Jersey: PrenticeHall.

Miller, D.T. \& Ratner, R.K. (1998). The disparity between the actual and assumed power of self interest Journal of Personality \& Social Psychology, Jg. 74.

Miller, G.J. (1992). Managerial Dilemmas. The Political Economy of Hierarchy. Cambridge: Cambridge University Press.

Mintzberg, H. (1980). The Nature of Managerial Work. $2^{\text {nd }}$ Edition. Englewood Cliffs.

Murphy, K.J. (1999). Executive Compensation. In O. Ashenfelter \& D. Card (Eds.), Handbook of Labour Economics: 2485-2563. Amsterdam: Elsevier. 
Nonaka, I. \& Takeuchi, H. (1995). The Knowledge-Creating Company. New York, Oxford: Oxford University Press.

Organ, D.W. (1988). Organizational Citizenship Behavior: The Good Soldier Syndrome. Lexington: Lexington Books.

Organ, D.W. \& Ryan, K. (1995). A meta-analytic review of attitudinal and dispositional predictors of organizational citizenship behavior. Personnel Psychology, 48, 775-782.

Osterloh, M. \& Frey, B.S. (2000). Motivation, Knowledge Transfer, and Organizational Firms. Organization Science, 11, 538-550.

Osterloh, M. \& Frey, B.S. (2004). Corporate Governance for Crooks. The Case for Corporate Virtue. In A. Grandori (Ed.): Corporate Governance and Firm Organization, Oxford University Press, forthcoming.

Osterloh, M., Rota, S. \& Kuster, B. (2003). Open Source Software Production. Climbing on the Shoulders of Giants. Working Paper, Institute for Research in Business Administration, University of Zurich.

Ostrom, E. (1998). A Behavioral Approach to the Rational-Choice Theory of Collective Action. American Political Science Review, 92, 1-22.

Ostrom, E. (2000). Crowding Out Citizenship. Scandinavian Political Studies, 23, 3-16.

Porac, J.F., Wade, J.B. \& Pollock, T.G. (1999). Industry Categories and the Politics of the Comparable Firm in CEO Compensation. Administrative Science Quarterly, 44, 112-144.

Rabin, M. (1998). Psychology and Economics. Journal of Economic Literature, 36, 11-46.

Rajan, R.G., \& Zingales, L. (1998). Power in a Theory of the Firm. The Quarterly Journal of Economics, 113, 387-432.

Raymond, E.S. (2000). The Magic Cauldron. http://www.tuxedo.org/ esr/writings/cathedralbazaar/magic-cauldron/index.html

Rousseau, D.M. (1995), Psychological Contracts in Organizations: Understanding Written and Unwritten Agreements, Thousand Oaks, London and New Delhi: Sage Publications.

Rowley, C.K., Tollison, R.D. \& Tullock, G. (eds.) (1988). The Political Economy of the Rent-Seeking Society. Boston: Kluwer.

Rummel, A. \& Feinberg, R. (1988). Cognitive Evaluation Theory: A Meta-Analytic Review of the Literature. Social Behavior and Personality, 16, 147-164.

Sally, D. (1995): Conversation and Cooperation in Social Dilemmas: A Meta Analysis of Experiments from 1958 to 1992. Rationality \& Society, 7, 58-92.

Salter, M. (2003). Innovation Corrupted: The Rise and Fall of Enron. HBR Case No. 903-032.

Schnatterly, K. (2003). Increasing Firm Value through Detection and Prevention of White-Collar-Crime. Strategic Management Journal, 24, 587-614.

Sen, A.K. (1974). Choice, Orderings and Morality. In S. Körner (Ed.), Practical Reason: Papers and Discussions, 54-67. Oxford: Blackwell. 
Simon, H.A. (1991). Organizations and Markets. Journal of Economic Perspectives, 5, 25-44.

Sliwka, D. (2003). On the Hidden Costs of Incentive Schemes. University of Bonn.

Spector, B. (2003). The Unindicted Co-conspirator. Organizational Dynamics, 32, 207-220.

Spender, J.C. (1996). "Making Knowledge the Basis of a Dynamic Theory of the Firm," Strategic Management Journal, 17 (Winter Special Issue), 45-62.

Stigler, G.J. \& Becker, G.S. (1977). De gustibus non est dispuntandum. American Economic Review 67, 76-90.

Stout, L.A. (2003), On the Proper Motives of Corporate Directors (Or, Why You Don't Want to Invite Homo Economicus to Join Your Board). University of California, Los Angeles - School of Law. Law and Economics Paper No.03-8.

Stukas, A.A., Snyder, M. \& Clary, E.G. (1999). The effects of "mandatory volunteerism" on intentions to volunteer. Psychological Science, 10 (1), 59-64.

Sundaramurthy, Ch. \& Lewis, M. (2003). Control and Collaboration. Paradoxes of Governance. The Academy of Management Review, 28 (3), 397-415.

Tang, S.H. \& Hall, V.C. (1995). The Overjustification Effect: A Meta-Analysis. Applied Cognitive Psychology, 9, 365-404.

Tenbrunsel, A.E. \& Messick, D.M. (1999). Sanctioning Systems, Decision Frames, and Cooperation. Administrative Science Quarterly, 44,4, 684-707.

The Economist, May $8^{\text {th }} 1999$, August $17^{\text {th }} 2002$, November $16^{\text {th }}, 2002$.

Thompson, J.D. (1967). Organizations in Action. New York: McGraw-Hill.

Titmuss, R.M. (1970). The Gift Relationship. London: Allen and Unwin.

Tollison, R.D. (1982). Rent Seeking: A Survey. Kyklos 35, 575-602.

Tosi , H.L., Werner, S., Katz, J.P. \& Gomez-Mejia, L.R. (2000). How much does performance matter? A meta-analysis of CEO pay studies. Journal of Management, 26, 301-339.

Tullock, G. (1967). The Welfare Costs of Tariffs, Monopolies and Theft. Western Economic Journal 5, 224-232.

Tyler, T.R. (1990). Why People Obey the Law. New Haven: Yale.

Tyler, T.R. (1999). Why people cooperate with organizations: An identity-based perspective. In R.I. Sutton and B.M. Staw (Eds.). Research in Organizational Behavior, 201-246. Greenwich, CT: JAI-Press.

Tyler, T.R. \& Blader, S. (2000). Cooperation in Groups: Procedural Justice, Social Identity, and Behavioral Engagement. Philadelphia: Psychology Press.

Tyler, T.R. \& Blader, S. (2003). Procedural Justice, Social Identity, and Cooperative Behavior. Personality and Social Psychology Review, 7, 349-361.

Tyler, T.R. \& Huo, Y.J. (2002). Trust in the Law. N.Y.: Russell-Sage. 
Tyler, T.R. \& Lind, E.A. (1992). A relational model of authority in groups. In M.P. Zanna (Ed.), Advances in Experimental Social Psychology, 115-192. Amsterdam: Academic Press (Elsevier).

Upton, W.E. (1973). Altruism, Attribution and Intrinsic Motivation in the Recruitment of Blood Donors. Ph.D. Dissertation. Abstract: Dissertation Abstracts International 34B (12), 1974: 6260. Cornell University.

Useem, J. (2003). Have They No Shame? Fortune, April 28, 2003 Vol. 147: 56-64.

Varian, H.R. (2002). Economic Scene, The New York Times, March 14, 2002. New York.

Vining, A.D. (2003). Internal Market Failure: A Framework for Diagnosing Firm Inefficiency. Journal of Management Studies, 40, 431-457.

Weber, Max (1978). Economy and Society: an Outline of Interpretative Sociology. Volumes 1 and 2. Berkeley; University of California Press.

Wiersma, U.J. (1992). The Effects of Extrinsic Rewards on Intrinsic Motivation: A Meta-Analysis. Journal of Occupational and Organizational Psychology, 65, 101-114.

Williamson, O.E. (1975). Markets and Hierarchies: Analysis and Antitrust Implications: A Study in the Economics of Internal Organization. New York: Free Press. 